\title{
Varicella-zoster virus encephalitis resembling herpes simplex virus encephalitis
}

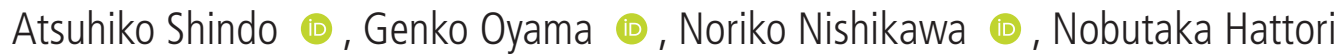

Department of Neurology, Juntendo University School of Medicine, Tokyo, Japan

\section{Correspondence to} Dr Genko Oyama; g_oyama@juntendo.ac.jp

Accepted 30 November 2021

\section{DESCRIPTION}

An 83-year-old woman with a history of Parkinson's disease developed a low-grade fever for 5 days. Despite oral antibiotic therapy, she was brought to the emergency department due to somnolence and fever $\left(40.2^{\circ} \mathrm{C}\right)$. On examination, the patient tested positive for Kernig's sign and jolt accentuation; further examination revealed reddish rashes with pain on her left hip. Fluid-attenuated inversionrecovery MRI revealed a high-intensity area (HIA) in the bilateral temporal poles (figure 1A). The cerebrospinal fluid (CSF) test revealed elevated total protein levels of $7570 \mathrm{mg} / \mathrm{L}$, cell count of $344 / \mu \mathrm{L}$ $(\mathrm{N} 32 / \mu \mathrm{L}, \mathrm{L} 312 / \mu \mathrm{L})$ and normal glucose levels. Positive varicella-zoster virus (VZV)-polymerase chain reaction (PCR) $\left(9.4 \times 10^{6}\right.$ copies) with negative herpes simplex virus (HSV)-PCR, anti-N-methyl$\mathrm{D}$-aspartate, voltage-gated potassium channel and paraneoplastic neurological syndrome antibodies confirmed the diagnosis of VZV limbic encephalitis. After acyclovir infusion for 3 weeks, VZVPCR results were negative and HIA disappeared (figure 1B). Her consciousness turned clear, and she was transferred to a rehabilitation hospital for the management of disuse weakness in the extremities.

In general, HSV infection is accompanied by limbic encephalitis with symmetrical high-intensity lesions in bilateral temporal lobes. ${ }^{1}$ In contrast, VZV infection is rarely accompanied by limbic encephalitis and typically shows asymmetrical, multiple infarcts due to angiitis. ${ }^{1}$ Indeed, encephalitis with VZV infection was reported in 5/18 (27.8\%) cases, and abnormal MRI findings were reported in 1/2 (50\%) cases. ${ }^{1}$ Although unilateral temporal lobe lesions have been reported in one case, ${ }^{2}$ there are no reports of symmetrical limbic lesions to our knowledge. Limbic encephalitis may develop due to viruses, autoimmune diseases and

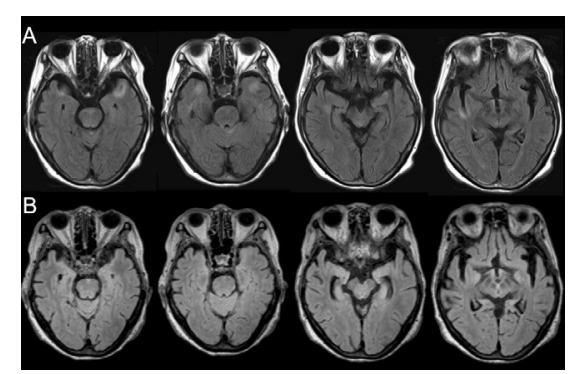

Figure 1 Brain MRI (fluid-attenuated inversionrecovery) (A) before treatment and (B) after treatment.

\section{Patient's perspective}

(Daughter) I was surprised that consciousness disturbance became progressively severe. However, I am glad that she is doing well at present.

\section{Learning points}

- Symmetrical high-intensity lesions in varicellazoster virus (VZV) encephalitis are rare.

- VZV encephalitis must be considered in the differential diagnosis of limbic encephalitis.

- Diagnostic clues for VZV encephalitis include typical rashes and polymerase chain reaction of skin swab and cerebrospinal fluid samples.

paraneoplastic syndrome. Even with atypical MRI presentation, VZV infection should be considered in the differential diagnosis for limbic encephalitis. The presence of rashes may aid the diagnosis, and a CSF VZV-PCR test should be performed for the definitive diagnosis.

Contributors Author roles; AS wrote the first draft, and GO, NN and $\mathrm{NH}$ contributed to the review and critique.

Funding The authors have not declared a specific grant for this research from any funding agency in the public, commercial or not-for-profit sectors.

Competing interests None declared.

Patient consent for publication Consent obtained directly from patient(s)

Provenance and peer review Not commissioned; externally peer reviewed.

Case reports provide a valuable learning resource for the scientific community and can indicate areas of interest for future research.

They should not be used in isolation to guide treatment choices or public health policy.

\section{ORCID iDs}

Atsuhiko Shindo http://orcid.org/0000-0002-6936-2478

Genko Oyama http://orcid.org/0000-0001-7985-5367

Noriko Nishikawa http://orcid.org/0000-0001-7762-3597

Nobutaka Hattori http://orcid.org/0000-0002-2034-2556

\section{REFERENCES}

1 Kaewpoowat Q, Salazar L, Aguilera E, et al. Herpes simplex and varicella zoster CNS infections: clinical presentations, treatments and outcomes. Infection 2016;44:337-45.

2 Tattevin P, Schortgen F, de Broucker T, et al. Varicella-zoster virus limbic encephalitis in an immunocompromised patient. Scand I Infect Dis 2001:33:786-8. 
Copyright 2021 BMJ Publishing Group. All rights reserved. For permission to reuse any of this content visit https://www.bmj.com/company/products-services/rights-and-licensing/permissions/

BMJ Case Report Fellows may re-use this article for personal use and teaching without any further permission.

Become a Fellow of BMJ Case Reports today and you can:

- Submit as many cases as you like

Enjoy fast sympathetic peer review and rapid publication of accepted articles

Access all the published articles

Re-use any of the published material for personal use and teaching without further permission

Customer Service

If you have any further queries about your subscription, please contact our customer services team on +44 (0) 2071111105 or via email at support@bmj.com.

Visit casereports.bmj.com for more articles like this and to become a Fellow 